\title{
Biochemical Changes in Ticks Infected Goats (Capra hircus) in Mhow Region (M.P.)
}

\author{
P. Sahu ${ }^{1}$, S. Gaherwal ${ }^{2}$ \\ ${ }^{1,2}$ Department of Zoology, Govt. Holkar Science College, Indore (M.P.), India
}

\begin{abstract}
The present study revealed that biochemical alteration were reported in all three season (rainy, summer and winter) in infected goat with ticks in Mhow region. Total 40 goats in which 10 control and 30 infected, selected for biochemical estimation and the parameters which were showed alteration in total protein, albumin, globulin, blood glucose, AST, ALT \& Bilirubin. In all three season total protein, albumin \& blood glucose decreased at $0,7 \& 21$ days as compared to control values. Globulin and bilrubin increased as compared to control value at same days. AST \& ALT increased at 0 days and decreased at $7 \& 21$ days as compared to control value.
\end{abstract}

Keywords: Biochemical parameters, AST \& ALT, Blood glucose etc.

\section{Introduction}

Goats are economically important short-day breeder ruminants (MacHugh and Bradley, 2001) which experience a variety of ecological challenges like wide variation in temperature, humidity and pathogenic invasions (Kaushalendra and Haldar, 2012), but never served as a favorable model and, hence, remained experimentally ignored. On the other hand, adaptation of animals for ecological stress makes them better survivors for which the metabolic strength of blood is highly important.

Blood, being the most important specialized tissue of the body, creates an open channel system to provide the equal amount of nutrients, hormones and other important factors to different organs. Thus, blood biochemistry is not only the important marker for the general health and basic metabolic pattern of an animal but it may also throw light on the adaptive modifications to different geographical distributions conditions (Somenath Ghosh et al., 2013).

Serum biochemical tests are widely used for the diagnosis of serious animal diseases which can lead to economic losses in animals like reduced fur, wool and milk production (Bani et al., 2008).

Looking to the importance of ticks infection and their harmful effects on goats specially on blood, the present investigation "Biochemical changes in ticks infected goats (Capra hircus) in Mhow region (M.P.)" was undertaken.

\section{Materials and Methods}

- Study area: Mhow (Indore region) was selected for the present study. Following Mhow villages were include for present study: Bhatiyakhera, Ahilyapur, Ambapur, Bai, Amada

- Experimental animal:

Goat (Capra Hircus) was selected for the present investigation. The survey and sample collection were done in 40 goats from Mhow.

- Experimental ectoparasite:
For the present study hard ticks were collect as ectoparasite on observed Capra hircus (Host).

- Collection of Blood sample:

The blood samples were taken in without EDTA tube from the jugular vein of each animal with a sterile disposable syringe. For biochemical studies, serum was separated from blood and kept immediately in refrigerator at $4^{\circ} \mathrm{C}$.

- Experiments:

Experiments were carried out in the following experimental and control group of goat (capra hircus).

- Non - infected (Control) group

This group was utilized for collection of blood to find out the normal value of biochemical parameter.

- Infected (Experimental) group

This group was utilized for collection of blood to find out the infected value of biochemical parameters. This group was divided in three categories- rainy, summer and winter season. Each category was 10 goats for the experimental purpose.

- Biochemical parameters

All the biochemical parameters were done which were total protein, albumin, globulin, blood glucose, AST, ALT and bilirubin.

\section{Results}

In all three season biochemical investigation of infected and control animal were summarized in table (1) and presented by graph (1, 2 and 3$)$.

In the present investigation the control (non-infected goat) biochemical values were total serum protein $(7.6 \pm 0.81 \mathrm{~g} / \mathrm{dl})$, albumin $(3.88 \pm 0.12 \mathrm{~g} / \mathrm{dl})$, globulin $(3.18 \pm 0.11 \mathrm{~g} / \mathrm{dl})$, blood glucose $(45.01 \pm 0.48 \mathrm{~g} / \mathrm{dl})$, SGPT or ALT $(32.47 \pm 3.12 \mathrm{u} / \mathrm{ml})$, SGOT or AST $(11.23 \pm 2.05 \mathrm{u} / \mathrm{ml})$ and serum bilirubin $(1.01 \pm 0.22 \mathrm{mg} / \mathrm{dl})$.

\section{Total Protein}

In the present investigation total protein values were $(6.85 \pm 0.22 \mathrm{~g} / \mathrm{dl}),(7.23 \pm 0.18 \mathrm{~g} / \mathrm{dl})$ and $(7.36 \pm 0.12 \mathrm{~g} / \mathrm{dl})$ in rainy season. In summer $(6.89 \pm 0.23 \mathrm{~g} / \mathrm{dl}),(6.6 \pm 0.21 \mathrm{~g} / \mathrm{dl})$ and $(6.58 \pm 1.01 \mathrm{~g} / \mathrm{dl})$ and in winter $(7.07 \pm 0.33 \mathrm{~g} / \mathrm{dl})$, 


\section{International Journal of Science and Research (IJSR) \\ ISSN (Online): 2319-7064 \\ Index Copernicus Value (2013): 6.14 | Impact Factor (2015): 6.391}

$(7.16 \pm 0.24 \mathrm{~g} / \mathrm{dl})$ and $(7.26 \pm 0.28 \mathrm{~g} / \mathrm{dl})$ at the $0,7 \& 21$ days respectively.

\begin{abstract}
Albumin
In the present investigation albumin values were $(3.56 \pm 0.09 \mathrm{~g} / \mathrm{dl}),(2.98 \pm 0.6 \mathrm{~g} / \mathrm{dl})$ and $(2.01 \pm 0.13 \mathrm{~g} / \mathrm{dl})$ in rainy season. In summer $(3.70 \pm 0.15 \mathrm{~g} / \mathrm{dl}),(3.05 \pm 0.10 \mathrm{~g} / \mathrm{dl})$ and $(2.88 \pm 1.01 \mathrm{~g} / \mathrm{dl})$ and in winter $(3.85 \pm 0.16 \mathrm{~g} / \mathrm{dl})$, $(3.55 \pm 0.20 \mathrm{~g} / \mathrm{dl})$ and $(3.38 \pm 0.31 \mathrm{~g} / \mathrm{dl})$ at the $0,7 \& 21$ days respectively.
\end{abstract}

\section{Globulin}

In the present investigation globulin values were $(3.18 \pm 0.11 \mathrm{~g} / \mathrm{dl}),(3.29 \pm 0.15 \mathrm{~g} / \mathrm{dl})$ and $(4.25 \pm 0.22 \mathrm{~g} / \mathrm{dl})$ in rainy season. In summer $(3.19 \pm 0.18 \mathrm{~g} / \mathrm{dl}),(3.55 \pm 0.25 \mathrm{~g} / \mathrm{dl})$ and $(3.70 \pm 0.33 \mathrm{~g} / \mathrm{dl})$ and in winter $(3.22 \pm 0.29 \mathrm{~g} / \mathrm{dl})$, $(3.61 \pm 0.31 \mathrm{~g} / \mathrm{dl})$ and $(3.88 \pm 0.38 \mathrm{~g} / \mathrm{dl})$ at the $0,7 \& 21$ days respectively.

\section{Blood glucose}

In the present investigation blood glucose values were $(41.22 \pm 0.35 \mathrm{~g} / \mathrm{dl}),(37.07 \pm 0.21 \mathrm{~g} / \mathrm{dl})$ and $(31.04 \pm 0.37 \mathrm{~g} / \mathrm{dl})$ in rainy season. In summer $(42.23 \pm 0.38 \mathrm{~g} / \mathrm{dl}),(38.55 \pm 0.25 \mathrm{~g} / \mathrm{dl})$ and $(34.18 \pm 0.41 \mathrm{~g} / \mathrm{dl})$ and in winter $(43.58 \pm 0.35 \mathrm{~g} / \mathrm{dl})$, $(40.01 \pm 0.29 \mathrm{~g} / \mathrm{dl})$ and $(35.21 \pm 0.41 \mathrm{~g} / \mathrm{dl})$ at the $0,7 \& 21$ days respectively.

SGPT or ALT (Serum glutamic pyruvic transaminase or Alanine amino transferase). In the present investigation SGPT values were $(78.19 \pm 5.69 \mathrm{u} / \mathrm{ml}),(60.14 \pm 4.01 \mathrm{u} / \mathrm{ml})$ and
$(41.79 \pm 3.58 \mathrm{u} / \mathrm{ml})$ in rainy season. In summer $(71.15 \pm 5.54 \mathrm{u} / \mathrm{ml}),(58.28 \pm 2.15 \mathrm{u} / \mathrm{ml})$ and $(47.41 \pm 2.17 \mathrm{u} / \mathrm{ml})$ and in winter $(69.36 \pm 2.58 \mathrm{u} / \mathrm{ml}),(55.08 \pm 2.33 \mathrm{u} / \mathrm{ml})$ and $(49.61 \pm 1.88 \mathrm{u} / \mathrm{ml})$ at the $0,7 \& 21$ days respectively.

SGOT or AST (Serum glutamic oxaloacetic transaminase or Aspartate amino transferase)

In the present investigation SGOT values were $(16.97 \pm 1.45 \mathrm{u} / \mathrm{ml}),(15.02 \pm 1.24 \mathrm{u} / \mathrm{ml})$ and $(14.23 \pm 1.11 \mathrm{u} / \mathrm{ml})$ in rainy season. In summer $(15.38 \pm 1.24 \mathrm{u} / \mathrm{ml}),(14.33 \pm 1.15$ $\mathrm{u} / \mathrm{ml})$ and $(13.11 \pm 1.02 \mathrm{u} / \mathrm{ml})$ and in winter $(14.17 \pm 1.25 \mathrm{u} / \mathrm{ml})$, $(13.02 \pm 1.14 \mathrm{u} / \mathrm{ml})$ and $(12.54 \pm 1.03 \mathrm{u} / \mathrm{ml})$ at the $0,7 \& 21$ days respectively.

\section{Bilirubin}

In the present investigation SGOT values were $(1.30 \pm 0.55 \mathrm{mg} / \mathrm{dl}),(1.57 \pm 0.01 \mathrm{mg} / \mathrm{dl})$ and $(1.72 \pm 0.02 \mathrm{mg} / \mathrm{dl})$ in rainy season. In summer $(1.25 \pm 0.66 \mathrm{mg} / \mathrm{dl}),(1.43 \pm 0.54$ $\mathrm{mg} / \mathrm{dl})$ and $(1.55 \pm 0.11 \mathrm{mg} / \mathrm{dl})$ and in winter $(1.20 \pm 0.47$ $\mathrm{mg} / \mathrm{dl}),(1.32 \pm 0.39 \mathrm{mg} / \mathrm{dl})$ and $(1.45 \pm 0.21 \mathrm{mg} / \mathrm{dl})$ at the 0,7 $\& 21$ days respectively.

Total protein, Albumin \& Blood glucose values were decreased and Globulin \& Bilirubin values were increased as compared to control value in rainy season then summer followed by winter season at 0,7 and 21 days. SGPT \& SGOT values were increased at 0 , and decreased at 7 and 21 days as compared to control value in rainy season then summer followed by winter season.

Table 1: Biochemical changes in hard ticks infected goat (Capra hircus) in different season at Mhow region.

\begin{tabular}{|c|c|c|c|c|c|c|c|c|c|c|}
\hline \multirow{4}{*}{ parameters } & \multirow{4}{*}{$\begin{array}{l}\text { Control } \\
\text { value }\end{array}$} & \multicolumn{3}{|c|}{ Rainy season } & \multicolumn{3}{|c|}{ Summer season } & \multicolumn{3}{|c|}{ Winter season } \\
\hline & & \multicolumn{3}{|c|}{$\begin{array}{l}\text { Experimental values } \\
\text { (Mean Values) }\end{array}$} & \multicolumn{3}{|c|}{$\begin{array}{c}\text { Experimental values } \\
\text { (Mean Values) }\end{array}$} & \multicolumn{3}{|c|}{$\begin{array}{l}\text { Experimental values } \\
\text { (Mean Values) }\end{array}$} \\
\hline & & \multicolumn{3}{|c|}{ Days interval } & \multicolumn{3}{|c|}{ Days interval } & \multicolumn{3}{|c|}{ Days interval } \\
\hline & & 0 days & 7 days & 21 days & 0 days & 7 days & 21days & 0 days & 7days & 21 days \\
\hline Total protein $(\mathrm{g} / \mathrm{dl})$ & $7.6 \pm 0.81$ & $6.85 \pm 0.22$ & $7.23 \pm 0.18$ & $7.36 \pm 0.12$ & $6.89 \pm 0.23$ & $6.6 \pm 0.21$ & $6.58 \pm 1.01$ & $7.07 \pm 0.33$ & $7.16 \pm 0.24$ & $7.26 \pm 0.28$ \\
\hline Albumin $(\mathrm{g} / \mathrm{dl})$ & $3.88 \pm 0.12$ & $3.56 \pm 0.09$ & $2.98 \pm 0.6$ & $2.01 \pm 0.13$ & $3.70 \pm 0.15$ & $3.05 \pm 0.10$ & $2.88 \pm 0.9$ & $3.85 \pm 0.16$ & $3.55 \pm 0.20$ & $3.38 \pm 0.31$ \\
\hline Globulin $(\mathrm{g} / \mathrm{dl})$ & $3.18 \pm 0.11$ & $3.29 \pm 0.15$ & $4.25 \pm 0.22$ & $5.35 \pm 0.31$ & $3.19 \pm 0.18$ & $3.55 \pm 0.25$ & $3.70 \pm 0.33$ & $3.22 \pm 0.29$ & $3.61 \pm 0.31$ & $3.88 \pm 0.38$ \\
\hline Blood glucose $(\mathrm{g} / \mathrm{dl})$ & $45.01 \pm 0.48$ & $41.22 \pm 0.35$ & $37.07 \pm 0.21$ & $31.04 \pm 0.37$ & $42.23 \pm 0.38$ & $38.55 \pm 0.25$ & $34.18 \pm 0.41$ & $43.58 \pm 0.35$ & $40.01 \pm 0.29$ & $35.21 \pm 0.41$ \\
\hline SGPT $(\mathrm{u} / \mathrm{ml})$ & $32.47 \pm 3.12$ & $78.19 \pm 5.69$ & $60.14 \pm 4.01$ & $41.79 \pm 3.58$ & $71.15 \pm 5.54$ & $58.28 \pm 2.15$ & $47.41 \pm 2.17$ & $69.36 \pm 2.58$ & $55.08 \pm 2.33$ & $49.61 \pm 1.88$ \\
\hline SGOT (u/ml) & $11.23 \pm 2.05$ & $16.97 \pm 1.45$ & $15.02 \pm 1.24$ & $14.23 \pm 1.11$ & $15.38 \pm 1.24$ & $14.33 \pm 1.15$ & $13.11 \pm 1.02$ & $14.17 \pm 1.25$ & $13.02 \pm 1.14$ & $12.54 \pm 1.03$ \\
\hline Bilirubin (mg/dl) & $1.01 \pm 0.22$ & $1.30 \pm 0.55$ & $1.57 \pm 0.01$ & $1.72 \pm 0.02$ & $1.25 \pm 0.66$ & $1.43 \pm 0.54$ & $1.55 \pm 0.11$ & $1.20 \pm 0.47$ & $1.32 \pm 0.39$ & $1.45 \pm 0.21$ \\
\hline
\end{tabular}

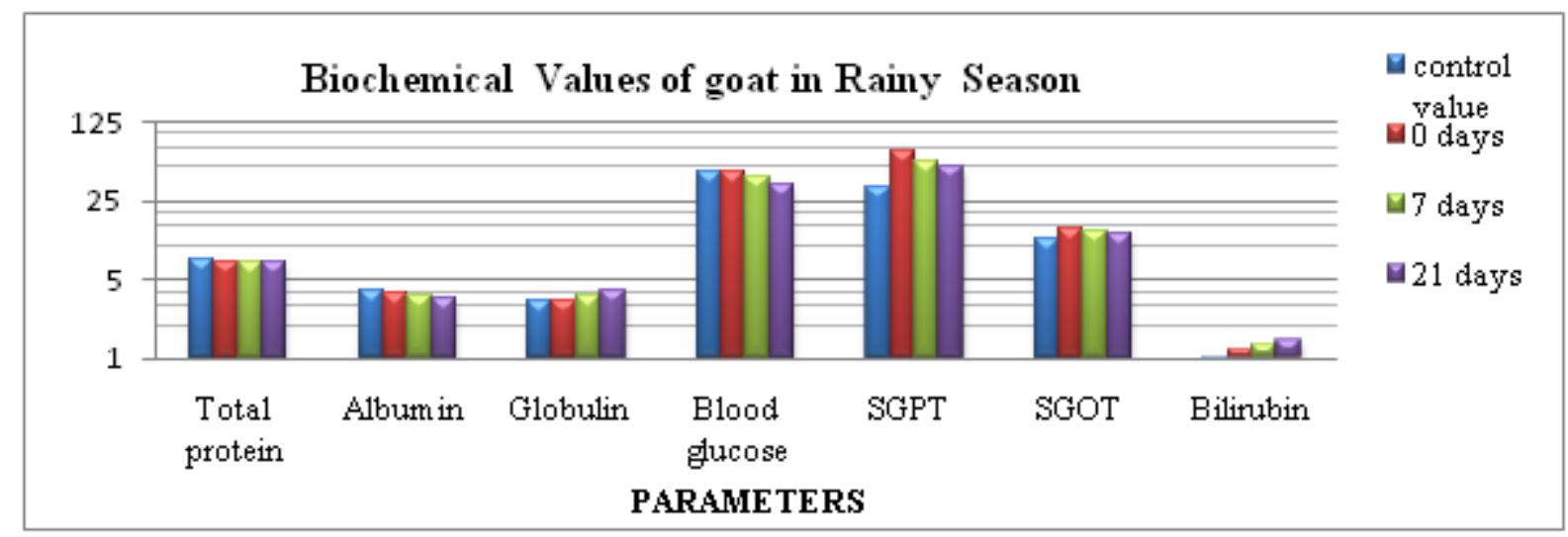

Figure 1: Graph presented Biochemical changes in hard ticks infected goat (Capra hircus) in rainy season at Mhow.

\section{Volume 5 Issue 6, June 2016 www.ijsr.net}




\section{International Journal of Science and Research (IJSR)}

ISSN (Online): 2319-7064

Index Copernicus Value (2013): 6.14 | Impact Factor (2015): 6.391

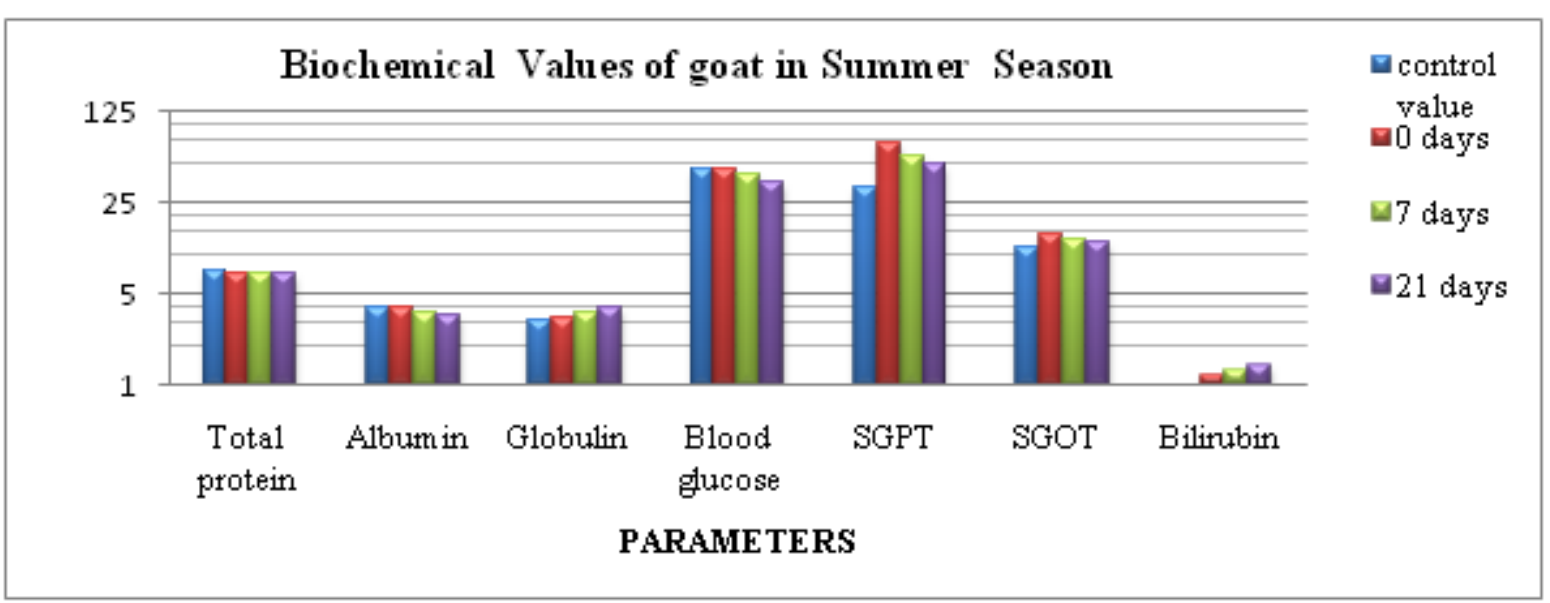

Figure 2: Graph presented Biochemical changes in hard ticks infected goat (Capra hircus) in summer season at Mhow.

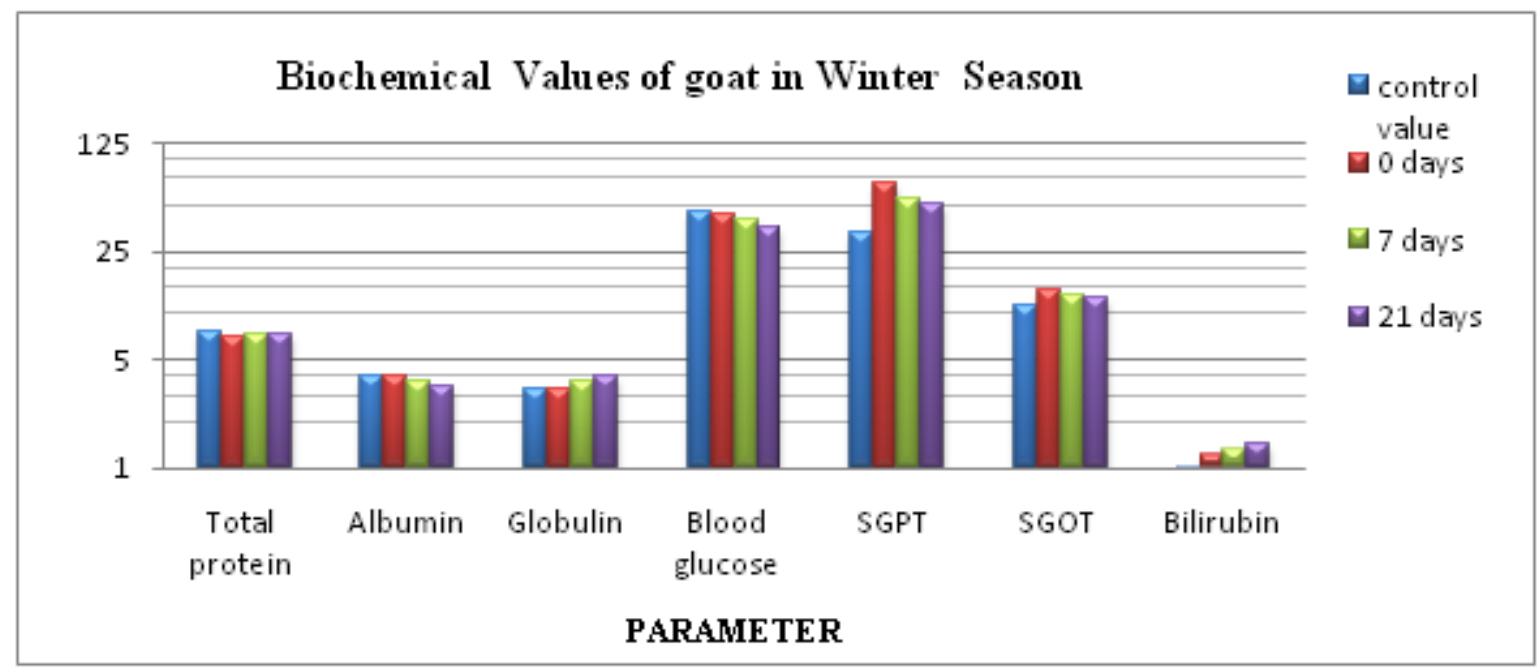

Figure 3: Graph presented Biochemical changes in hard ticks infected goat (Capra hircus) in summer season at Mhow.

\section{Discussion}

In the present study biochemical values were altered in infected goat as compared to control goat. Total protein, Albumin \& Blood glucose values were decreased and Globulin \& Bilirubin values were increased as compared to control value in rainy season then summer followed by winter season at 0,7 and 21 days. SGPT \& SGOT values were increased at 0 , and decreased at 7 and 21 days as compared to control value in rainy season then summer followed by winter season.

Arvind kumar et al. ( 2010) observed the biochemical parameters viz. total protein, albumin, globulin, glucose, bilirubin, AST and ALT were estimated in goats of village flock of natural infested and goats infected experimentally with ticks and found that total protein, globulin were higher at 21 than 0 day infection and non infection control. There was significant difference in total protein and globulin values between day 21 of experimental infected goats and natural infested goats of village from the day 0 and control group of animals

Rajendran and Hafeez (2003) and Padmaja et al. (2006) also reported significant decrease in total serum protein, albumin in tick infested animals which are in close agreement with our findings. Bilirubin, ALT and AST levels were significantly higher in tick infected animal than the control and day 0 groups of animals. Dalpati et al. (1997) reported decrease in blood glucose, serum protein level in ixodid tick infected animals. The findings also gain support with the findings of Belozerov (1982), Chhabra et al. (1983), Gray (1991), Das (1994) and Clover and Lane (1995).

It was concluded that ticks infection caused the significant alteration in the biochemical values of goat. Total protein, glucose and albumin were lower while globulin, AST, ALT and bilirubin were higher in infected animal. The results of present study supported above mention data given by author.

\section{References}

[1] Arvind, K., Vihan, V.S., Sadhna, S. and Sharma, H.N. (2010) Hematological and biochemical effects of tick infestation in common Indian goat in Mathura. Ind. j. Animal Sci.1:163-168.

[2] Belozerov, V.N.(1982). Diapause and biological rhythms in ticks in : physiology of ticks, F.D.Obencham and R.Galun, Pergamom Press, Oxford pp, 469-500.

[3] Bani IZA, Al-Majali AM, Amireh F, Al-Rawashreh OF. Metabolic profile in goat does in late pregnancy with and without subclinical pregnancy toxemia. Vet Clin Pathol. 2008; 37:434-437. 


\section{International Journal of Science and Research (IJSR) \\ ISSN (Online): 2319-7064}

Index Copernicus Value (2013): 6.14 | Impact Factor (2015): 6.391

[4] Chhabra, M.B., Ruprah, N.S. and Gupta, S.K. (1983). Cited in Das, S.S. (1994). Prevalence of ixodid ticks infestation on farm animals in Pantnagar, Tarai of Uttar Pradesh,.J.Parasit.Appl.Anim, Biol.,3:71-73.

[5] Clover, J.R. and Lane, R.S.(1995). Evidence implicating nymphal ixodes pacificus (Acari: Ixodidae) in the epidemiology of lyme diseases in California. Am.J. Trop.Med. Hyg. 53:237-24.

[6] Dalpati, M.R., Bhowmik, M.K., Sarrar, S., Samsal, N.K. (1997) Demodicosis of goat: haeamtological and biochemical changes, Tropical animal Health and Production, 29:240-242.

[7] Das, S.S.,(1994). Prevalence of ixodid ticks infestation on farma animal in Pantanagar, Tarai of Uttar Pradesh J. Parasiti.Appl.Anim.Biol.,3:71-73.

[8] Gary, J.S. (1991). The development and seasonal activity of ticks.ixodes rimsra vector of lyme bonchosis. Med.Vet.Entomol. 79:323-333.

[9] Kaushalendra, Haldar, C. (2012). Correlation between peripheral melatonin and general immune status of domestic goat Capra hircus: A seasonal and sexdependant variation. Small Ruminant Res 107: 146-156.

[10] MacHugh, D.E. and Bradley, D.G. (2001). Livestock genetic origins: goats buck the trend. Proc Nat Acad Sci, USA 98: 5382-5384.

[11] Padmaja, B., Kumar Satish, K. Haritha, C. (2006). Haematological and blood biochemical profile of sheep with mixed endoparasitic infestation. Indian Vet.J.,83: 634-636.

[12] Rajendran, C. and Hafeez, M.D. (2003). Haematobiochemical changes and efficacy of different acaricides in crossbred animal. Ind.J. Animal Sci., 73(5): 481-483.

[13] Somenath, G., Amaresh, K. and Chandana, H. (2013).Adaptive and ecological significance of the seasonal changes in hematological, biochemical and hormonal parameters in the tropical goat Capra hircus in uttarpardesh India. J Endocrinol Reprod 2: 113122.

Volume 5 Issue 6, June 2016 www.ijsr.net 